\title{
Development and characterization of five rainbow trout pituitary single-cell clone lines capable of producing pituitary hormones
}

\author{
Maria J Chen, Pinwen Peter Chiou, Yu-Hsian Liao, Chun-Mean Lin and Thomas T Chen \\ Department of Molecular and Cell Biology, University of Connecticut, 91 North Eagleville Road, U-3125 Storrs, Connecticut 06269, USA \\ (Correspondence should be addressed to T T Chen; Email: thomas.chen@uconn.edu) \\ (P P Chiou is now at Marine Research Station, Institute of Cellular and Organismal Biology, Academia Sinica, Yilan, Taiwan, ROC)
}

\begin{abstract}
Five single-cell clone lines (mRTP1B, mRTP1E, mRTP1F, mRTP1K, and mRTP2A) have been developed from adult rainbow trout pituitary glands. These cell lines have been maintained in a $\mathrm{CO}_{2}$-independent medium supplemented with 10\% fetal bovine serum (FBS) for more than 150 passages. At about 150 passages, the doubling time of each single-cell clone in a $\mathrm{CO}_{2}$-independent medium supplemented with $10 \% \mathrm{FBS}$ at $20^{\circ} \mathrm{C}$ was $3 \cdot 6 \pm 0 \cdot 7,2 \cdot 8 \pm 0 \cdot 7$, $3 \cdot 2 \pm 0 \cdot 8,5 \cdot 5 \pm 0 \cdot 6$, and $6 \cdot 6 \pm 0 \cdot 6$ days respectively. Each single-cell clone contains $60 \pm 2$ chromosomes, which is within the range of the $2 \mathrm{~N}$ chromosome numbers reported for rainbow trout. Reverse transcription-PCR analysis revealed that in addition to expressing $g h$, prolactin $(\mathrm{prl})$, and estradiol $\left(\mathrm{E}_{2}\right)$ receptor $\alpha(e 2 r \alpha$ or esr 1$)$ genes, each single-cell clone line also expressed other pituitary-specific
\end{abstract}

genes such as tsh, gonadotropin 1 (gth-1 or $f s h b$ ), gonadotropin 2 (gth-2 or $(h b)$, somatolactin (sl or smtl), proopiomelanocortin-B (pomcb), and corticosteroid receptor (cr or $n r 3 c 1$ ). Immunocytochemical analysis showed that all the five single-cell clones produced both $\mathrm{Gh}$ and Prl. Furthermore, the expression of $g h$ and $p r l$ genes in the single-cell clone lines is responsive to induction by $\mathrm{E}_{2}$, dexamethasone, and $o, p^{\prime}$-dichlorodiphenyltrichloroethane. All together, these results confirm that each of the singlecell clones was derived from rainbow trout pituitary glands. These single-cell clone lines not only can be used to study factors that regulate the expression of pituitary hormone genes, but can also be developed as a rapid screening system for identifying environmental endocrine disruptors.

Journal of Endocrinology (2010) 205, 69-78

\section{Introduction}

Development of in vitro systems is crucial for understanding the mechanism of regulation of pituitary hormone gene expression at the molecular level in fish. Whole pituitary gland cultures (Yada et al. 1991, Elango et al. 2006) and dissociated pituitary gland primary cell cultures (Le Goff et al. 1992) are the two in vitro systems that have been used to study factors that regulate the production and secretion of GH and prolactin (PRL) in the pituitary of rainbow trout (Oncorhynchus mykiss). Both systems are considered short term, with cultures usually only being able to be maintained for about 1 week. There are several drawbacks associated with these two systems for studying the expression of $g h$ and $p r l$ genes. Since the pituitary gland of fish is very small, pituitary glands from many fish have to be used for establishing any pituitary gland explant culture, and this will lead to a great variability within an experiment or between experiments because of the variability among fish. In addition, setting up pituitary gland explant cultures is further limited by the seasonal availability of sufficient numbers of fish which can receive experimental manipulation. The specific drawback of using primary pituitary cell cultures stems from the step of dissociating pituitary glands. This step can be difficult to reproduce consistently, and the dissociated cells frequently require a period of time to recover, during which the expression of certain genes could be detrimentally affected. For instance, as reported by Le Goff et al. (1992), the expression of prl gene in the rainbow trout primary pituitary cell cultures dropped significantly during the first 2 days of the cultures. Additionally, primary pituitary cell cultures can only be maintained for 1 week; new cultures need to be prepared in order to repeat any experiment. Almost all these problems could be overcome if continuous pituitary cell lines that can produce pituitary peptide hormones are available. Unfortunately, very few fish pituitary cell lines are available to date (Ribeiro \& Ahne 1982, Bols \& Lee 1991, Bols et al. 1995).

The first mammalian pituitary cell lines $\left(\mathrm{GH}_{3}\right.$ cells, four clonal strains) capable of synthesizing GH and PRL were established from rat pituitary tumors many years ago (Yasumura et al. 1966, Tashjian et al. 1968, 1970), and these cell lines have been proven useful in a wide range of studies (Ool et al. 2004, for review). Furthermore, Chomczynski et al. (1988) also have developed a cell line (somatomammotroph cells, rPCO) from the normal pituitary of an adult rat. Although the tumor cell lines can grow indefinitely in 
culture, the rPCO line was developed without any immortalizing treatment and yet has been maintained in culture for more than 1 year (over 45 passages).

The advances in recombinant DNA and protein purification technologies in the past 20 years have generated abundant knowledge on the structures of GH, PRL, somatolactin (SL or SMTL), one of the GH family proteins found only in fish (Ono et al. 1990, Rand-Weaver et al. 1991), and other pituitary hormones in fish. While some of the hormonal and environmental factors that regulate the expression of pituitary hormone genes have been identified in mammals, factors that regulate the expression of these genes in fish remain to be fully determined due to lack of reliable pituitary cell lines. Although a cell line has been developed from rainbow trout pituitary glands (Bols \& Lee 1994, Bols et al. 1995), this cell line has a few drawbacks. First, instead of being a clonal strain, this cell line contains a mixed population of pituitary cell types, which will bring serious variability from experiment to experiment. Secondly, upon continued culturing passing passage 50 , this cell line was shown to have lost its ability to express $g h, p r l$, and $s l$ (smtl) genes. Thus, there is still an urgent need to develop a permanent clonal fish pituitary cell line.

Shamblott \& Chen (1992) reported the existence of four isoforms of pro-insulin-like growth factor 1 (IGF1) that encode identical mature IGF1 but four different forms of pro-peptides, namely Ea1, Ea2, Ea3, and Ea4. In our laboratory, Tian et al. (1999) showed that recombinant rainbow trout E-peptides (rtEa4 and rtEa2) of the pro-IGF1 exerted mitogenic activity in BALB/NIH3T3 cells, human embryonic kidney cells (293GP), and caprine mammary epithelial cells (CMECs). It is conceivable that $\mathrm{rtEa} 2$ or $\mathrm{rtEa} 4$ may serve as an effective mitogenic agent in rainbow trout primary pituitary cells. Elango et al. (2006) showed that while the expression of $g h$ gene in the trout pituitary organ culture was induced by $17 \beta$-estradiol $\left(\mathrm{E}_{2}\right)$, dexamethasone, and $o, p^{\prime}$-dichlorodiphenyltrichloroethane $\left(o, p^{\prime}\right.$-DDT), the expression of $p r l$ gene was induced only by $\mathrm{E}_{2}$ and $o, p^{\prime}-\mathrm{DDT}$. Therefore, we reasoned that a functional trout pituitary cell line should be responsive to induction of $g h$ and $p r l$ gene expression by these factors. In this report, we describe the development and characterization of five single-cell clone lines capable of expressing $g h, p r l$, thyroid-stimulating hormone $(t s h)$, gonadotropin 1 (gth-1 or $f s h)$, gonadotropin 2 (gth-2 or $\operatorname{lhb}$ ), corticosteroid receptor ( $\mathrm{cr}$ or $n \mathrm{nr} \mathrm{c} 1)$, proopiomelanocortin-B (pomcb), and $s l$ (smtl) genes from rainbow trout pituitary glands.

\section{Materials and Methods}

\section{Establishment of cell lines}

Whole pituitary glands including pars intermedia were collected from five female rainbow trout of 1 year of age under sterile conditions, and were rinsed three times in
Dulbecco's PBS (Gibco-BRL) containing penicillin $(1000 \mathrm{U} / \mathrm{ml})$, streptomycin $(1000 \mu \mathrm{g} / \mathrm{ml})$, and fungizon (25 $\mu \mathrm{g} / \mathrm{ml}$; Gibco-BRL). These glands were minced together into fine pieces (smaller than $0.5 \mathrm{~mm}$ cubes), and seeded in a $\mathrm{T}-25$ flask in a $\mathrm{CO}_{2}$-independent medium (Gibco-BRL) supplemented with fetal bovine serum (FBS, 10\%; Gibco$\mathrm{BRL}$ ), bovine growth factor (bGF, $5 \mathrm{ng} / \mathrm{ml}$; Gibco-BRL), penicillin $(250 \mathrm{U} / \mathrm{ml})$, streptomycin $(250 \mu \mathrm{g} / \mathrm{ml})$, and fungizone $(2.5 \mu \mathrm{g} / \mathrm{ml})$, and the culture was incubated in an incubator at $20{ }^{\circ} \mathrm{C}$. After tissues and cells attached to the substratum, the old medium was carefully removed and replaced with fresh $\mathrm{CO}_{2}$-independent medium containing $10 \% \mathrm{FBS}, 100 \mathrm{U} / \mathrm{ml}$ penicillin, $100 \mathrm{mg} / \mathrm{ml}$ streptomycin, and $5 \mathrm{ng} / \mathrm{ml} \mathrm{bGF}$, and the culture was left in the incubator. Cells grown out from the tissue were trypsinized in a PBS solution containing $0 \cdot 25 \%$ of trypsin and $0.02 \%$ of EDTA, and the detached cells were recovered by gentle centrifugation and divided into two aliquots. Cells from one aliquot $\left(5 \times 10^{5}\right.$ cells) were seeded in a T-25 flask in $\mathrm{CO}_{2}$-independent medium supplemented with $10 \% \mathrm{FBS}, 5 \mathrm{ng} / \mathrm{ml} \mathrm{bGF}$, $100 \mathrm{U} / \mathrm{ml}$ penicillin, and $100 \mu \mathrm{g} / \mathrm{ml}$ streptomycin, and about the same number of cells from another aliquot were seeded in a T-25 flask in the same type of medium but supplemented with $4 \mu \mathrm{g} / \mathrm{ml}$ recombinant $\mathrm{rtEa} 4$-peptide of pro-IGF1 (Tian et al. 1999). While cells cultured in the medium without trout Ea4-peptide supplement died within 2 weeks, cells cultured in the medium with trout Ea4-peptide supplement continued to grow. Cells were subcultured in 1/4 dilutions in the same type of medium once a week for 15 passages, and at this time, the penicillin-streptomycin mixture was excluded from the culture medium.

Single-cell clones were isolated from the culture at 15 passages using the method described by Chen et al. (2004). Cells were diluted to 3 cells $/ \mathrm{ml}$ in a conditioned $\mathrm{CO}_{2}$-independent medium supplemented with $10 \%$ FBS and $4 \mu \mathrm{g} / \mathrm{ml}$ recombinant trout Ea4-peptide. To each 96-well plate, $0.2 \mathrm{ml}$ of the diluted culture was plated in each well, and the plates were incubated at $20^{\circ} \mathrm{C}$. The 96-well plates were examined under an inverted microscope, and wells that contained a single cell were marked. Once the single-cell clone grew to cover more than half of the well, cells were recovered and seeded into $\mathrm{T}-25$ flasks in $\mathrm{CO}_{2}$-independent medium supplemented with 10\% FBS for further propagation. Each single-cell clone was subcultured once a week over 150 passages. Seed stocks were prepared by freezing $3 \times 10^{6}$ cells/vial in a $\mathrm{CO}_{2}$-independent medium supplemented with 10\% FBS and 5\% dimethyl sulfoxide, and were stored in liquid nitrogen.

\section{Preparation of recombinant rtEa4-peptide}

Recombinant rtEa4-peptide was prepared according to the method described by Tian et al. (1999) and modified by Kuo \& Chen (2002), and was stored at $4{ }^{\circ} \mathrm{C}$. 


\section{Karyotyping}

Metaphase chromosomes were prepared from cells arrested in metaphase with $0 \cdot 2 \mu \mathrm{g} / \mathrm{ml}$ colcemid (Gibco-BRL) for $3 \mathrm{~h}$ following the method described below. Metaphase-arrested cells were treated with $5 \mathrm{ml}$ of $0 \cdot 25 \%$ trypsin until cells dissociated from the surface of the culture flasks. Cells were then resuspended in $5 \mathrm{ml}$ of fresh $\mathrm{CO}_{2}$-independent medium supplemented with $10 \%$ FBS, and were collected by centrifugation at $300 \mathrm{~g}$ for $5 \mathrm{~min}$ (Beckman GS-6R). The cell pellet was treated with $5 \mathrm{ml}$ of $75 \mathrm{mM} \mathrm{KCl}$ and gently resuspended in an additional $25 \mathrm{ml}$ of the same concentration of $\mathrm{KCl}$ solution. The cell suspension was incubated at $20^{\circ} \mathrm{C}$ for $30 \mathrm{~min}$ and spun at $300 \mathrm{~g}$ for $5 \mathrm{~min}$. The cell pellet was resuspended in $7 \mathrm{ml}$ of a fixative (methanol-acetic acid, 3:1) followed by centrifugation. The treatment with the fixative was repeated four times, and the cell pellet was resuspended in the fixative in a final volume of $2 \mathrm{ml}$. These cells were then broken on glass slides by gravity to release chromosomes by dripping the cell mixture from a suitable distance above the slides. Chromosomes were stained using the Giemsa stain method (Gustasaw et al. 1994), and were observed at $\times 1000$ magnification with an oil immersion objective under a light microscope (Olympus $1 \times 50$ ). About 500 mitotic figures from each single-cell clone were counted, and the chromosome number was in the range of $60 \pm 2$.

\section{Determining the doubling time}

About $1 \times 10^{4}$ cells of each single-cell clone were resuspended in the $\mathrm{CO}_{2}$-independent medium supplemented with $10 \%$ FBS and plated in each well of 96-well plates, and the cultures were incubated in an incubator at $20^{\circ} \mathrm{C}$. At different time intervals, cultures were removed from the incubator, medium was removed, and the cultures were kept in a $-80{ }^{\circ} \mathrm{C}$ freezer. The DNA content in each well was determined by staining the DNA with Hoechst dye (H33258) and was quantified in a fluorescence multiwell plate reader, Cytofluor II (Framingham, MA, USA). The doubling time of each single-cell clone was determined from a plot of DNA content versus culturing time.

\section{Colony formation in soft agar medium}

Colony formation assay was conducted following the method described by Yang (1975). About $5 \times 10^{4}$ cells from each single-cell clone at log phase were suspended in $0.5 \mathrm{ml}$ of $\mathrm{CO}_{2}$-independent medium containing $10 \%$ FBS and $0 \cdot 4 \%$ purified agar (Difco Laboratories, Detroit, MI, USA) and plated in 24-well culture chambers that contained a solidified layer of agar $(0.5 \%)$ dissolved in $\mathrm{CO}_{2}$-independent medium. After the medium had solidified, each well was overlaid with $1.5 \mathrm{ml}$ of $\mathrm{CO}_{2}$-independent medium with $10 \%$ FBS. The plates were incubated in an incubator at $20{ }^{\circ} \mathrm{C}$ for $4-5$ weeks. Colonies were observed under an Olympus inverted microscope $(1 \times 50)$ equipped with phase contrast objective lenses (final magnification $\times 100$ ). Colonies with sizes $>50 \mu \mathrm{m}$ were scored. The viability of cells at the end of the experiment was confirmed by the dye exclusion assay with trypan blue. Four wells were prepared for each single-cell clone, and the experiment was repeated twice.

\section{Detection of $\mathrm{Gh}$ and $\mathrm{Prl}$ by immunocytochemical staining}

Cells of mRTP1E $_{52}$ were cultured in an eight-well glass culture chamber with $\mathrm{CO}_{2}$-independent medium supplemented with $10 \%$ FBS to $80-90 \%$ confluence, and were fixed with $4 \%$ paraformaldehyde. Nonspecific binding was blocked by incubating cells in PBS containing 1\% dry milk powder and $0 \cdot 2 \%$ Triton $\mathrm{X}-100$ at $4{ }^{\circ} \mathrm{C}$ overnight. Cells were incubated with a 1:10 dilution of monospecific universal antiGh or anti-Prl sera raised in rabbits (Gonzalez-Villasenor \& Chen 1999) at $4{ }^{\circ} \mathrm{C}$ overnight. Following washing in PBS containing $0 \cdot 2 \%$ Triton X-100, the cells were subsequently incubated in PBS containing $0 \cdot 2 \%$ Triton $\mathrm{X}-100$ and $6.5 \mu \mathrm{g} / \mathrm{ml}$ of FITC-conjugated mouse-antirabbit $\operatorname{IgG}$ at $4{ }^{\circ} \mathrm{C}$ overnight. The immunostained cells were observed by fluorescence microscopy (Olympus $1 \times 50$ microscope) at $400 \times$, and images were taken using a MicroMAX CCD camera (Princeton Instrument, Bozeman, MT, USA). Negative control slides were also prepared by the same procedures as described, but without incubation with primary antibodies.

To determine whether the same single-cell clone was synthesizing both $\mathrm{Gh}$ and $\mathrm{Prl}$, an immuno-double staining was conducted as described below. Cells of five single-cell clones were cultured in an eight-well glass culture chamber with $\mathrm{CO}_{2}$-independent medium supplemented with $10 \%$ FBS to $80-90 \%$ confluence, induced with $1 \times 10^{-8} \mathrm{M}$ of $\mathrm{E}_{2}$ for $4 \mathrm{~h}$, treated with $2 \cdot 5 \mu \mathrm{g} / \mathrm{ml}$ of brefeldin A (Fujiwara et al. 1988) for $45 \mathrm{~min}$ to inhibit the export of Gh or Prl from the cells, and fixed with $4 \%$ paraformaldehyde. Nonspecific binding of the cells was blocked by the method described above. Monospecific anti-Gh and anti-Prl were labeled with DyLight $_{488}$ and DyLight 594 respectively following protocols provided by the supplier (Thermo Scientific, Waltham, MA, USA). The fixed cells were incubated with a 1:100 dilution of the DyLight-labeled monospecific universal anti-Gh and anti-Prl sera at $4{ }^{\circ} \mathrm{C}$ overnight. Following washing in PBS containing $0 \cdot 2 \%$ Triton $\mathrm{X}-100$, the immunostained cells were observed by fluorescence microscopy (Olympus $1 \times 50$ microscope, at 493-518 $\mathrm{nm}$ for $\mathrm{Gh}$ and at 593-618 $\mathrm{nm}$ for Prl) at $1000 \times$ magnification, and images were taken using a MicroMAX CCD camera.

\section{Detection of $m R N A$ by RT-PCR analysis}

Total RNA was isolated from each mRTP single-cell clone or pituitary glands according to the acid-guanidinium thiocyanate-phenol-chloroform extraction method (Chomczynski \& Sacchi 1987). The total RNA was further treated with RNase-free DNase to remove any trace 
Table 1 Annealing conditions and amplification oligonucleotide primer sequences used in reverse transcription (RT)-PCR $\left({ }^{*}\right)$ and real-time RT-PCR

\section{Primer sequence}

\begin{tabular}{|c|c|}
\hline \multicolumn{2}{|l|}{ Gene } \\
\hline \multirow[t]{2}{*}{ gh1 } & F: 5'-ACATACTCAACCGACCACCGC \\
\hline & R: 5'-GCCTAATCTGTATCTGGGAA \\
\hline \multirow[t]{2}{*}{ gh2 } & F: 5'-CTGTAACTCTGACTCCATCGTG \\
\hline & R: 5'-CCCACTTTGAGGTCGCTGAG \\
\hline \multirow[t]{2}{*}{$r t E 2 R \alpha(e s r 1)$} & F: 5'-СССТТСТТССССТССАСССС \\
\hline & R: 5'-GCCGCCCCACСАССТCCGC \\
\hline \multirow[t]{2}{*}{ prl } & F: 5'-TCACTCAGCАСТTСССТСАСС \\
\hline & R: 5'-CCAGGAGGAGGGAGCGAGCC \\
\hline \multirow[t]{2}{*}{ 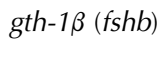 } & F: 5'-ATCGTCACGGAAGCATCACC \\
\hline & R: 5'-CGGGTATGAGAGAGGGCTCG \\
\hline \multirow[t]{2}{*}{ 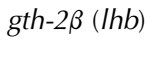 } & F: 5'-GАTСТСССТGСТTСТGTGC \\
\hline & R: 5'-GCTCCTTGGTGACGCAGTGG \\
\hline \multirow[t]{2}{*}{$\operatorname{tsh} \beta$} & F: 5'-AATGTGACTTCTGCGTGGC \\
\hline & R: 5'-ACGGGGTAGGTGAAGACAGG \\
\hline \multirow[t]{2}{*}{ pomcb } & F: 5'-GATGGGTCACTTCCGCTGG \\
\hline & R: 5'-CTGCTGСССТССТСТАСТGC \\
\hline \multirow[t]{2}{*}{$\operatorname{cr}(n r 3 c 1)$} & F: 5'-ACTGTCTCTGTTCTGGTCTTCG \\
\hline & R: 5'-GGCTCTCTGСТСССТTTCGC \\
\hline \multirow[t]{2}{*}{ sl (smtl) } & F: 5'-AGAAGGACGCCACAAGATG \\
\hline & R: 5'-GGCACCAGAAGCAGGGAGG \\
\hline \multirow[t]{2}{*}{$\beta$-Actin } & F: 5'-GAGCAGGAGATGGGCACC \\
\hline & R: 5'-CCGCAAGACTCCATACCGA \\
\hline
\end{tabular}

Annealing Product (temperature/s) size (bp)

$\begin{array}{lll}48{ }^{\circ} \mathrm{C} / 15 \mathrm{~s} & 756 & \text { Genbank M22731 } \\ 50{ }^{\circ} \mathrm{C} / 15 \mathrm{~s} & 200 & \text { Genbank M24684 } \\ 57{ }^{\circ} \mathrm{C} / 15 \mathrm{~s} & 248 & \text { Genbank AJ242740 } \\ 59 \cdot 5^{\circ} \mathrm{C} / 15 \mathrm{~s} & 178 & \text { Genbank M24738 } \\ 58 \cdot 5^{\circ} \mathrm{C} / 15 \mathrm{~s} & 177 & \text { Genbank M27153 } \\ 58 \cdot 5^{\circ} \mathrm{C} / 15 \mathrm{~s} & 161 & \text { Genbank AB050836 } \\ 58 \cdot 5^{\circ} \mathrm{C} / 15 \mathrm{~s} & 193 & \text { Genbank D14692 } \\ 59 \cdot 5^{\circ} \mathrm{C} / 15 \mathrm{~s} & 146 & \text { Genbank X69808 } \\ 59 \cdot 5^{\circ} \mathrm{C} / 15 \mathrm{~s} & 229 & \text { Genbank NM_001124730 } \\ 59 \cdot 5^{\circ} \mathrm{C} / 15 \mathrm{~s} & 195 & \text { Genbank D10640 } \\ 59 \cdot 5{ }^{\circ} \mathrm{C} / 15 \mathrm{~s} & 149 & \text { Genbank AF157514 }\end{array}$

Reference

Genbank AF157514 contamination by genomic DNA. First-strand cDNA was synthesized from each RNA sample using Superscript II (Invitrogen) according to the manufacturer's recommendation with modification. Briefly, 3-5 $\mu \mathrm{g}$ of total RNA were incubated with $100 \mathrm{ng}$ oligo $(\mathrm{dT})_{12-15}$ in an $11-\mu$ volume at $70{ }^{\circ} \mathrm{C}$ for $5 \mathrm{~min}$, followed by a quick chill on ice. Subsequently, $4 \mu \mathrm{l}$ of $5 \times$ first-strand buffer (Invitrogen), $1 \mu \mathrm{l}$ of $0.1 \mathrm{M}$ dithiothreitol, $1 \mu \mathrm{l}$ of RNasin (40 unit/ $\mu \mathrm{l}$, Promega), and $1 \mu \mathrm{l}$ of $10 \mu \mathrm{M}$ dNTP mixed stock were added and incubated at $42{ }^{\circ} \mathrm{C}$ for $2 \mathrm{~min}$, followed by addition of 200 units of Superscript III. The reaction was allowed to proceed at $42{ }^{\circ} \mathrm{C}$ for $90 \mathrm{~min}$ and terminated by heating at $70{ }^{\circ} \mathrm{C}$ for $15 \mathrm{~min}$. A Tris-EDTA buffer was added to bring the final volume of the reaction mixture up to $200 \mu \mathrm{l}$, and the cDNA was stored at $-20{ }^{\circ} \mathrm{C}$ until further use.

PCR was conducted with $3 \mu$ of the diluted first-strand cDNA in a total volume of $50 \mu \mathrm{l}$ using standard buffer conditions as described by the manufacturer (Promega),
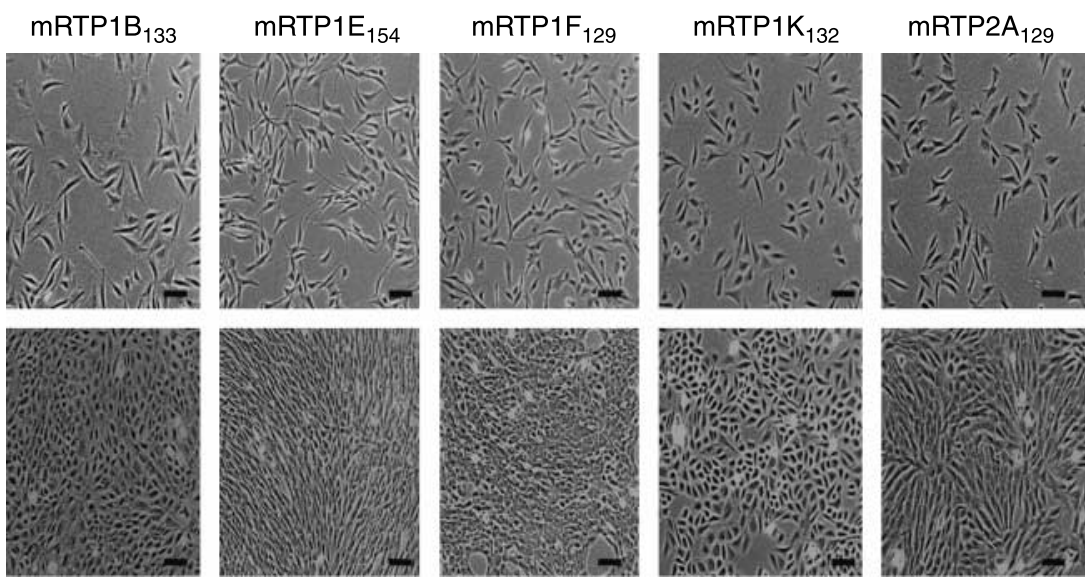

$100 \mu \mathrm{m}-$

Figure 1 Morphological characteristics of five single-cell lines, mRTP1B, mRTP1E, mRTP1F, mRTP1K, and mRTP2A. Sub-confluent cells (panel A) and confluent cells (panel B) were observed by light microcopy with an Olympus $1 \times 50$ microscope. Subscript indicates the passage number of each single-cell clone. 
Table 2 Doubling time of pituitary single-cell clones

\begin{tabular}{ll} 
& Doubling time (days) \\
\cline { 2 - 2 } Single-cell clones & \\
mRTP1B $_{155}$ & $3 \cdot 6 \pm 0 \cdot 7$ \\
mRTP1E $_{176}$ & $2 \cdot 8 \pm 0 \cdot 7$ \\
mRTP1F $_{151}$ & $3 \cdot 2 \pm 0 \cdot 8$ \\
mRTP1K $_{153}$ & $5 \cdot 5 \pm 0 \cdot 6$ \\
mRTP2A $_{125}$ & $6 \cdot 6 \pm 0 \cdot 6$ \\
\hline
\end{tabular}

supplemented with $1.5 \mathrm{mM} \mathrm{MgCl}_{2}, 200 \mu \mathrm{M}$ dNTP, $400 \mathrm{nM}$ each gene-specific primer (Table 1), and 1 unit of Taq polymerase (Promega). The following PCR profile was used: denaturation at $94^{\circ} \mathrm{C}$ for $3 \mathrm{~min}$, followed by 40 cycles consisting of $94{ }^{\circ} \mathrm{C}$ for $20 \mathrm{~s}$ for denaturation, $48-60^{\circ} \mathrm{C}$ for $15-20 \mathrm{~s}$ (depending on the primer set) for annealing, and $72{ }^{\circ} \mathrm{C}$ for $30 \mathrm{~s}$ for synthesis. The PCR products were resolved on $1.5 \%$ agarose gels stained with $0.1 \mu \mathrm{g} / \mathrm{ml}$ ethidium bromide.

Levels of $g h, p r l, t s h \beta, g t h-1 \beta, g t h-2 \beta, p o m c b, c r$, and $s l$ mRNAs were determined by relative quantitative real-time reverse transcription (RT)-PCR following the protocol provided by the supplier (Roche Applied Science). The amplification primers used in the PCR are described in Table 1. First-strand cDNA was prepared by RT as described earlier, and $2 \mu \mathrm{l}$ of the first-strand cDNA were used for PCR in $16 \mu \mathrm{l}$ of reaction volume. PCR conditions were as follows: denaturation at $95^{\circ} \mathrm{C}$ for $10 \mathrm{~min}$ and followed by 50 cycles of amplification $\left(95^{\circ} \mathrm{C}\right.$ for $15 \mathrm{~s}, 60^{\circ} \mathrm{C}$ for $15 \mathrm{~s}$, and $72{ }^{\circ} \mathrm{C}$ for $30 \mathrm{~s})$. A melting curve program $\left(95-55^{\circ} \mathrm{C}\right)$ with a heating rate of $0.5^{\circ} \mathrm{C} / 10 \mathrm{~s}$ was also included to confirm the specificity of the amplification. PCR efficiencies of all the reactions were between 95 and $100 \%$. Relative expression levels were calculated as $2^{-(\Delta \mathrm{CTs}-\Delta \mathrm{CTc})}$, where $\Delta \mathrm{CTs}$ $=$ critical cycle number $(\mathrm{CT})$ of hormone treated $-\mathrm{CT}$ of $\beta$-actin and $\Delta \mathrm{CTc}=\mathrm{CT}$ of hormone untreated-CT of $\beta$-actin. All measurements were performed in triplicate and repeated at least three times. The data were analyzed using iCycler Thermal Cycler analysis software (Optical System Interface version 2.3).

Induction of $g$ h and prl $m R N A s$ by $E_{2}$, dexamethasone, and $\mathrm{o}, \mathrm{p}^{\prime}-D D T$

Cells of mRTP1B were cultured in a $\mathrm{CO}_{2}$-independent medium supplemented with $10 \%$ FBS to $80-90 \%$ confluence, starved in a $\mathrm{CO}_{2}$-independent medium supplemented with $2 \cdot 5 \%$ charcoal-dextrin-stripped FBS for $24 \mathrm{~h}$, and then incubated in the fresh $\mathrm{CO}_{2}$-independent medium supplemented with $2 \cdot 5 \%$ charcoal-dextrin-stripped FBS and various concentrations of $\mathrm{E}_{2}\left(10^{-8}\right.$ and $\left.10^{-7} \mathrm{M}\right)$, dexamethosone $\left(10^{-8}\right.$ and $\left.10^{-7} \mathrm{M}\right)$ or $o, p^{\prime}$-dichlorodiphenyltrichloroethane $\left(o, p^{\prime}-\mathrm{DDT} ; 5 \times 10^{-7}\right.$ and $\left.1 \times 10^{-6} \mathrm{M}\right)$ for another $24 \mathrm{~h}$. Control cells were cultured in a $\mathrm{CO}_{2}-$ independent medium supplemented with $2.5 \%$ charcoaldextrin-stripped FBS and the equivalent amount of vehicle used to dissolve the hormones. Total RNA was isolated from treated and control cells following the method described in the previous section, and was used as a template for first-strand cDNA synthesis. Double-stranded cDNA of specific mRNA was amplified by PCR using first-strand cDNA as a template. Conditions for RT-PCR were the same as described in the previous section, and nucleic acid sequences for PCR amplification primers are listed in Table 1.
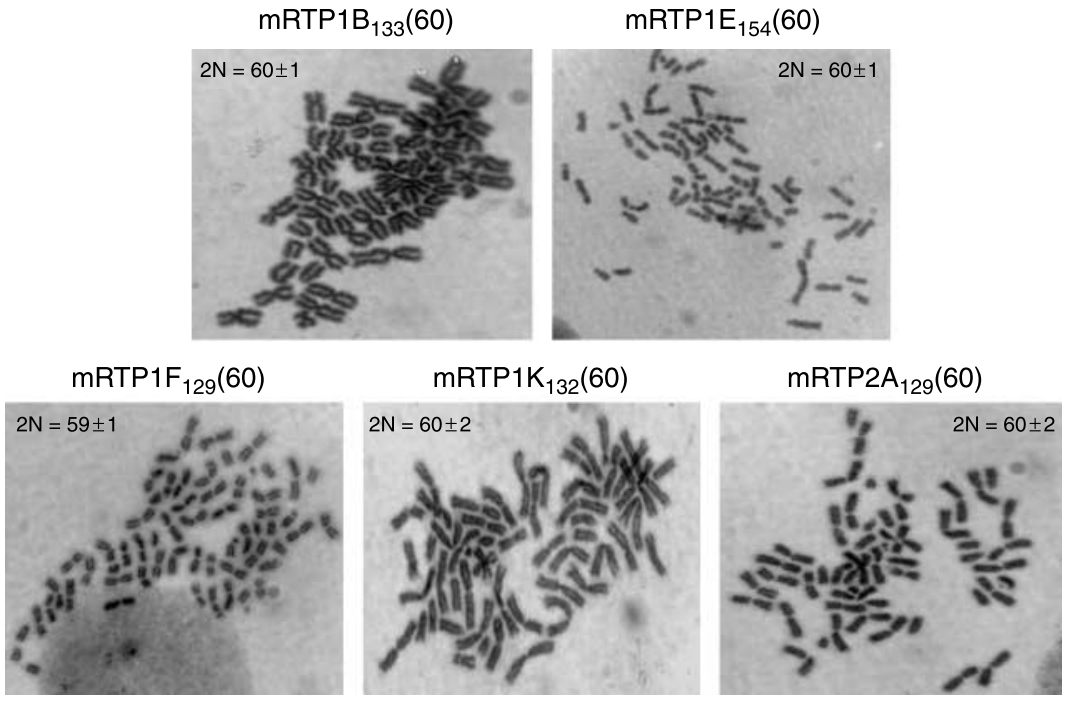

Figure 2 Metaphase chromosomes of rainbow trout pituitary single-cell clones. Subscript indicates the passage number of each single-cell clone. Magnification: $\times 1000$. 
Table 3 Colony formation activity of trout pituitary single-cell clones determined in a soft agar medium. Mean \pm s.D.

\section{Number colonies/view ${ }^{\mathrm{a}}$}

\section{Single-cell clones}

$\begin{array}{lr}\text { mRTP1 }_{155} & 8 \pm 2 \\ \text { mRTP1E }_{176} & 10 \pm 1 \\ \text { mRTP1F }_{151} & 39 \pm 3 \\ \text { mRTP1 }_{153} & 16 \pm 1 \\ \text { mRTP2A }_{126} & 1 \pm 1\end{array}$

${ }^{\mathrm{a}}$ Number of colonies were counted per view under a microscope; each data point is the average of four independent counting.

\section{Results}

Several single-cell clones were isolated from primary pituitary cells by the serial dilution cloning method (Chen et al. 2004). After single-cell clones were isolated, rtEa4-peptide was no longer included in the culture medium. Five single-cell clones (mRTP1B, mRTP1E, mRTP1F, mRTP1K, and mRTP2A)

A
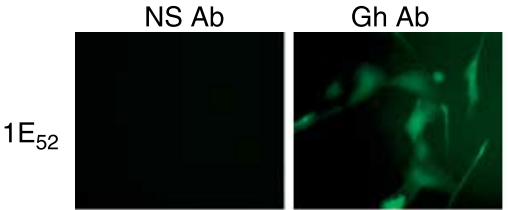

NS Ab
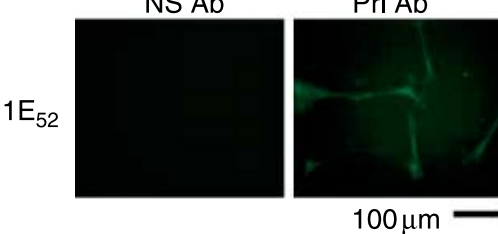

B

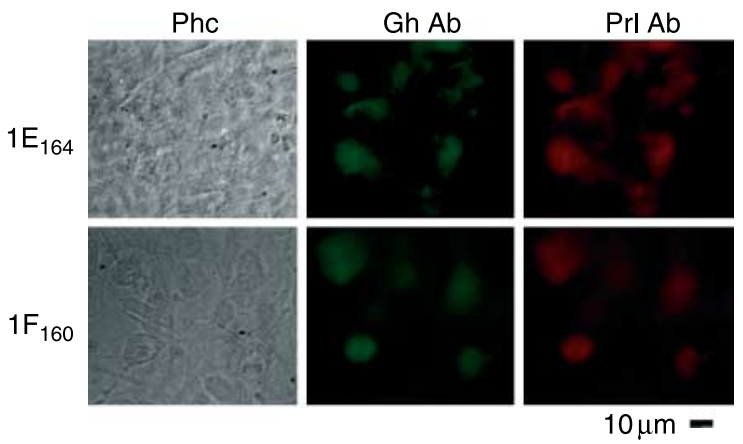

Figure 3 Representative data of $\mathrm{Gh}$ and $\mathrm{Prl}$ produced in $\mathrm{mRTP}$ single-cell clones by immunocytochemical staining. (A) mRTP1E cells stained with FITC-labeled monospecific GH antisera or monospecific Prl antera; (B) mRTP1E 164 and mRTP1F 160 cells co-stained with DyLight 488 -labeled monospecific $\mathrm{GH}$ antisera and DyLight $_{594}$-labeled monospecific PRL antisera. Protocol of the immunostaining is described in 'Materials and Methods', and the stained cells were observed under an Olympus $1 \times 50$ microscope equipped with an epifluorescence attachment. NS Ab, nonspecific antisera; $\mathrm{Gh} \mathrm{Ab}$, monospecific $\mathrm{Gh}$ antisera; $\mathrm{Prl} \mathrm{Ab}$, monospecific $\mathrm{Prl}$ antisera; $\mathrm{PhC}$, phase contrast objective. were selected for further characterization based on their morphological characteristics (Fig. 1). At a lower cell density, mRTP1E $_{154}$ displayed a fibroblast-like spindle structure with protruding extensions often longer than the main body of the cell. The other four mRTP cell lines, although elongated, were more epithelium-like in morphology. At confluence, the five mRTP cell lines were highly diverse in morphology. Visibly, mRTP1E 154 cells were fibroblast-like, whereas mRTP1K $_{132}$ cells were epithelium-like. Both mRTP1B $_{133}$ and $\mathrm{mRTP}_{2} \mathrm{~A}_{129}$ cells displayed elongate epithelium-like morphology. In contrast to the generally uniform morphology observed in the other mRTP single-cell clones, mRTP1F 129 cells were highly pleomorphic and basophilic, features that are often associated with malignant tumors.

Each of these single-cell clones had gone through at least 150 passages, and the doubling time for each single-cell clone at passages 126-176 was determined to be $3 \cdot 6 \pm 0 \cdot 7 \mathrm{~d}$ for $\operatorname{mRTP}_{13} B_{155}, 2 \cdot 8 \pm 0 \cdot 7 \mathrm{~d}$ for $\mathrm{mRTP}_{1} \mathrm{E}_{170}, 3 \cdot 2 \pm 0 \cdot 8 \mathrm{~d}$ for $\mathrm{mRTP}_{151}, 5 \cdot 5 \pm 0 \cdot 6 \mathrm{~d}$ for $\mathrm{mRTP}_{1 \mathrm{~K}} \mathrm{~K}_{153}$, and $6 \cdot 6 \pm 0.6 \mathrm{~d}$ for mRTP2 $_{126}$ (Table 2). On the basis of their morphologies and different doubling times, we suggest that each of these five single-cell clones represents a different origin. The chromosome number of each single-cell clone was determined by karyotyping, and the results (Fig. 2) show that the chromosome numbers for these five single-cell clones ranged from $59 \pm 1$ to $60 \pm 2$, within the range of the $2 \mathrm{~N}$ chromosome numbers reported for rainbow trout (Philips 2001). The in vitro colony formation activities determined in the soft agar medium for all the single-cell clones are summarized in Table 3, with RRTP1F $_{151}$ showing the highest colony formation activity and $\mathrm{mRTP}_{2} \mathrm{~A}_{126}$ the lowest. We had noted that mRTP1F cells exhibited highly pleomorphic and basophilic morphology and high activity of colony formation in soft agar medium, and that these features are often associated with malignancy.

Cells from all the five single-cell clones were stained positive with antisera to $\mathrm{Gh}$ and $\mathrm{Prl}$ (see representative figures in Fig. 3A and B), suggesting that these cells produce Gh and Prl simultaneously. Furthermore, total RNA samples

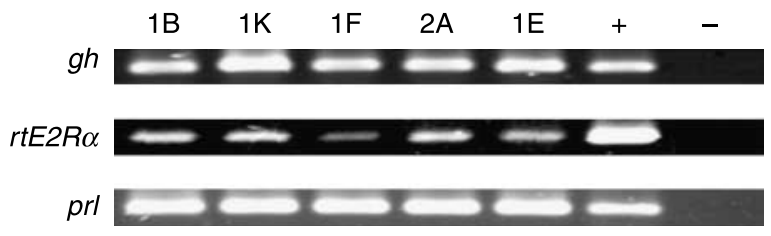

Figure 4 RT-PCR determination of $g h, 17 \beta-E_{2}$ receptor, and $p r l$ mRNAs in mRTP single-cell clones. Total RNA was isolated from mRTP single-cell clones and used as a template for first-strand cDNA synthesis. Double-stranded cDNA of specific mRNA was amplified by PCR using first-strand cDNA as a template. Conditions for RT-PCR are described in 'Materials and Methods', and nucleic acid sequences of gene-specific primers for PCR amplification are listed in Table 1. PRL, prolactin; rtE2R $\alpha$, trout $E_{2}$ receptor $\alpha ; 1 \mathrm{~B}$, mPRT1B; 1K, mPRT1K; 1F, mPRT1F; 2A, mPRT2A; 1E, mPRT1E; + , cDNA prepared from pituitary mRNA; - , no template added. 


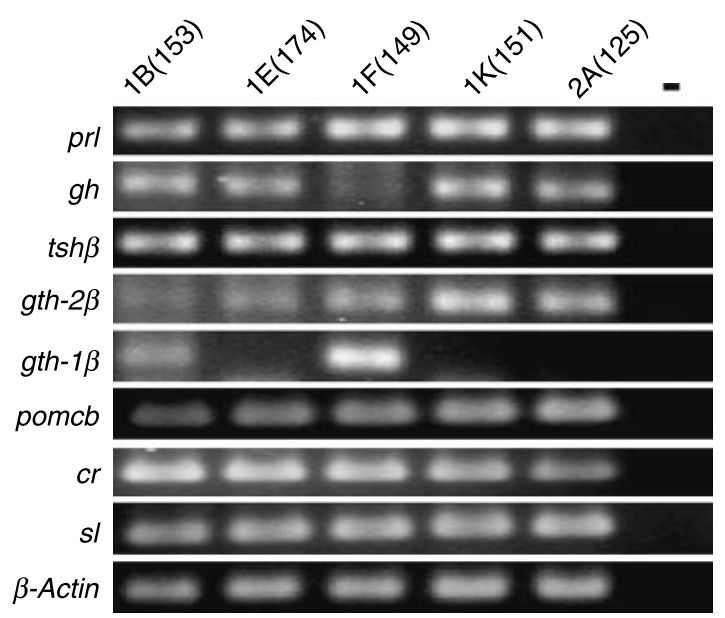

Figure 5 RT-PCR determination of $g h, p r l, t s h \beta, g t h-1 \beta$, gth- $2 \beta$, pomcb, $c r, s l$, and $\beta$-actin mRNAs in mRTP single-cell clones. Total RNA was isolated from mRTP single-cell clones and used as a template for first-strand cDNA synthesis. Double-stranded cDNA of specific mRNA was amplified by PCR using first-strand CDNA as a template and gene-specific oligonucleotides as amplification primers. Conditions for RT-PCR are described in 'Materials and Methods', and sequences of oligonucleotides for PCR amplification are listed in Table 1. prl, prolactin; tsh $\beta$, thyroid-stimulating hormone $b$ subunit; gth- $1 \beta$, gonadotropin $1 \beta$ subunit; gth- $2 \beta$, gonadotropin $2 \beta$ subunit; pomcb, proopiomelanocortin- $B$; $\mathrm{Cr}$, corticosteroid receptor; sl, somatolactin; 1B, mPRT1B; 1E, mPRT1E; 1F, mPRT1F; $1 \mathrm{~K}$, mPRT1K; $2 \mathrm{~A}, \mathrm{mPRT} 2 \mathrm{~A}$. Numbers in the parentheses indicate passages of each single-cell clone used in this study.

isolated from cells of all the five single-cell clones were analyzed for the presence of $g h, p r l, p i t-1$ (pou1f1), and estrogen receptor $(r t E 2 R \alpha)$ mRNAs by RT-PCR analysis. The results of the RT-PCR analysis revealed that while all the five single-cell clones produced mRNAs of $\mathrm{gh}, \mathrm{prl}$, and $r t E 2 R \alpha$, no pit-1 mRNA (data not shown) was detected (Fig. 4). To address the question whether each of these five single-cell clones also produces other pituitary hormones, mRNA from each cell clone was analyzed for the production of Tsh $\beta$, Gth- $1 \beta$, Gth- $2 \beta$, Pomcb, Cr, and Sl by RT-PCR and relative quantitative RT-PCR, and the results are presented in Figs 5 and 6 . To our surprise, while clones $1 \mathrm{~B}$ and $1 \mathrm{~F}$ produced $g h, p r l, t s h \beta, g t h-1 \beta$, gth- $2 \beta$, pomcb, $c r$, and $s l$ mRNAs, clones $1 \mathrm{E}, 1 \mathrm{~K}$, and $2 \mathrm{~A}$ produced all mRNA species except gth $-1 \beta$ mRNA. Furthermore, levels of $s l$ mRNA in clones $1 \mathrm{~B}$ and $1 \mathrm{~K}$ were much lower than those in clones $1 \mathrm{E}, 1 \mathrm{~F}$, and $2 \mathrm{~A}$.

It was shown previously that while levels of $g h$ mRNA in pituitary glands of rainbow trout maintained in organ culture were modulated by $\mathrm{E}_{2}$, dexamethasone, and $o, p^{\prime}$-DDT, levels of $p r l$ mRNA were only modulated by $\mathrm{E}_{2}$ and $o, p^{\prime}$-DDT (Elango et al. 2006). To determine whether the single-cell clones established in this study are also responsive to induction by $\mathrm{E}_{2}$, dexamethasone, and $o, p^{\prime}$-DDT, mRNA was isolated from mRTP1E clone following treatment with various doses of $\mathrm{E}_{2}$, dexamethasone, or $o, p^{\prime}$-DDT and was subjected to semi-quantitative RT-PCR analysis. As shown in Fig. 7, while levels of $g h$ mRNA were induced by $E_{2}$, dexamethasone, and $o, p^{\prime}$-DDT, levels of $P R L$ mRNA were only induced by $\mathrm{E}_{2}$ and $o, p^{\prime}$-DDT. Furthermore, the responsiveness of the mRTP1E clone to induction of GH and $P R L$ mRNAs by $\mathrm{E}_{2}$ at passages 35 and 125 was indistinguishable (Fig. 8).

\section{Discussion}

Intensive efforts over several decades by scientists to develop continuous fish pituitary cell lines capable of expressing pituitary hormone genes have achieved only limited success. Although a trout pituitary cell line (RTP-2) was developed by Bols \& Lee (1994) and Bols et al. (1995), this cell line contained a mixture of different pituitary cell types. While this cell line was shown to express $g h$ and $p r l$ genes at passage 50 (Bols et al. 1995), it failed to maintain this characteristic upon prolonged culturing. In our study, five single-cell clone lines were developed from normal appearing primary cultures of rainbow trout pituitary glands without treatment with any known immortalization agent. Since each of these single-cell clones has gone through at least 150 passages, these clones should be considered as permanent cell lines. Karyotype analysis showed that each of these five single-cell clones contains from $59 \pm 1$ to $60 \pm 2$ chromosome complements, which are in good agreement with the reported $2 \mathrm{~N}$ chromosome number for rainbow trout (Philips 2001). It is interesting to note that while primary trout pituitary cells in the presence of recombinant trout

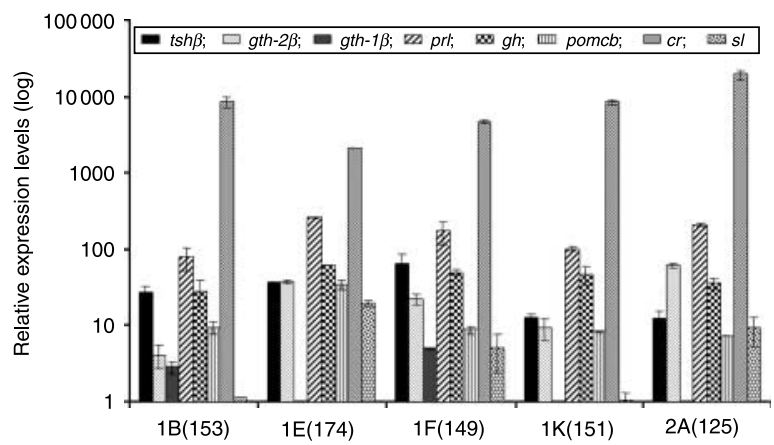

Figure 6 Levels of $g h, p r l, t s h \beta$, gth- $1 \beta$, and gth- $2 \beta$ mRNAs in mRTP single-cell clones determined by relative quantitative real-time RT-PCR analysis. Total RNA was isolated from mRTP single-cell clones and used as a template for first-strand cDNA synthesis. Double-stranded cDNA of specific mRNA was amplified by PCR using first-strand CDNA as a template and gene-specific oligonucleotides as amplification primers following conditions described in 'Materials and Methods', and sequences of oligonucleotides for PCR amplification are listed in Table 1. Relative expression levels were calculated as $2^{-(\Delta \mathrm{CTs}-\Delta \mathrm{CTC})}$. 1B, mPRT1B; mPRT1K, mPRT1F; 2A, mPRT2A; mPRT1E. Numbers in the parentheses indicate passages of each single-cell clone used in this study. Each data point indicates mean \pm s.D. $(n=3)$. 
A

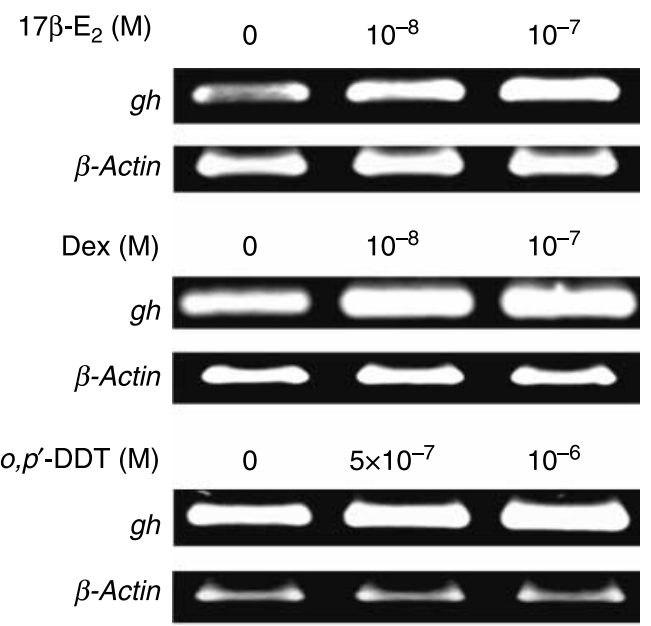

B

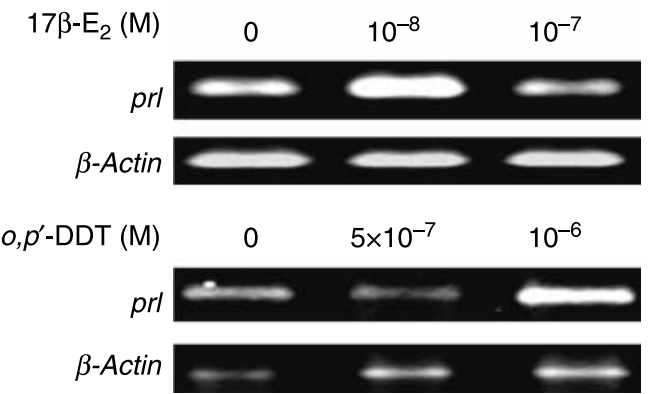

Figure 7 RT-PCR determination of $g h(\mathrm{~A})$ and $p r / m R N A(B)$ in mRTP1E single-cell clone induced by $17 \beta$-estradiol, dexamethasone, or $o, p^{\prime}$-DDT. Cells of mRTP1E were cultured in $\mathrm{CO}_{2}$-independent medium supplemented with $10 \%$ FBS to $80-90 \%$ confluence, starved in $\mathrm{CO}_{2}$-independent medium supplemented with $2.5 \%$ charcoal-dextrin-stripped FBS for $24 \mathrm{~h}$, and then incubated in the same medium type supplemented with various concentrations of $17 \beta$-estradiol, dexamethasone, or $o, p^{\prime}$-DDT for another $24 \mathrm{~h}$. Total RNA was isolated from treated cells and used as a template for first-strand cDNA synthesis. Double-stranded cDNA of specific mRNA was amplified by PCR using first-strand CDNA as a template. Conditions for RT-PCR are described in 'Materials and Methods', and nucleic acid sequences of PCR amplification primers are listed in Table 1.

Ea4-peptide (the pro-peptide sequence of the pro-IGF1) supplement grew well and led to the development of permanent single-cell clones, primary pituitary cells died in 2 weeks after their establishment without the supplementation of trout Ea4-peptide in the culture medium. Together with the fact that recombinant trout Ea4-peptide exerted mitogenic activity in nontransformed NIH3T3 and primary CMECs (Tian et al. 1999), it is suggested that trout Ea4-peptide may serve as an immortalization agent for the development of single-cell clones in this study.

A useful pituitary cell line should maintain its ability to produce pituitary-specific proteins such as Gh, Prl, and other peptide hormones. Immunocytochemical analysis with monospecific antisera of $\mathrm{Gh}$ and $\mathrm{Prl}$ showed that cells of all the five single-cell clones produced both Gh and Prl. This observation was further supported by results of RT-PCR analysis that mRNAs of $g h, p r l$, tsh, gth-1, gth-2, sl, pomcb, $c r$, and $r t E 2 R \alpha$ genes were detected in each of these five singlecell clones. Immunocytochemical studies of fish pituitary glands showed that there are seven to eight types of distinct secretory cells in the adenohypophysis, each of which produces different hormones: Prl, Gh, Tsh, Gth-1, Gth-2, Acth, melanophore-stimulating hormone, and S1 (Doerr-Schott 1976, Follenius et al. 1978, Nagahama et al. 1981, Farbridge \& Leatherland 1986, Saga et al. 1999). On the basis of these results, it is believed that each cell type of the fish adenohypophysis in vivo produces only one type of the pituitary hormone. To our surprise, results of RT-PCR and relative quantitative real-time RT-PCR analyses revealed that each single-cell clone was able to produce Gh, Prl, Tsh, Gth-1, Gth-2, Pomcb, Cr, and Sl. A similar observation was made earlier in $\mathrm{GH}_{3}$ cells, a cell line derived from a rat anterior pituitary tumor (Tashjian et al. 1968, 1970, Yasumura et al. 1966) and somatomammotrophs derived from adult rat pituitary glands (Chomczynski et al. 1988), which are capable of synthesizing Gh and Prl. The reason for this

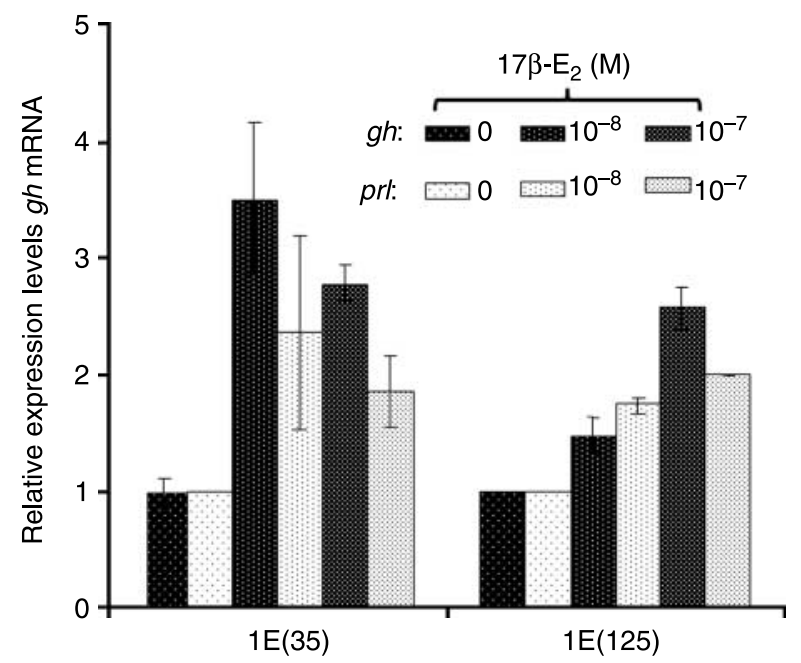

Figure 8 Induction of $g h$ and $p r l$ mRNAs in mPRT1E cells by $17 \beta$-estradiol at different passages. Cells of mRTP1E were cultured in $\mathrm{CO}_{2}$-independent medium supplemented with $10 \%$ FBS to $80-90 \%$ confluence, starved in $\mathrm{CO}_{2}$-independent medium supplemented with $2 \cdot 5 \%$ charcoal-dextrin-stripped FBS for $24 \mathrm{~h}$, and then incubated in the same medium type supplemented with various concentrations of $17 \beta$-estradiol for another $24 \mathrm{~h}$. Total RNA was isolated from treated cells and used as a template for first-strand cDNA synthesis. Double-stranded cDNA of specific mRNA was amplified by PCR using first-strand cDNA as a template. Conditions for relative quantitative RT-PCR are described in 'Materials and Methods', and nucleic acid sequences of PCR amplification primers are listed in Table 1. Numbers in the parentheses indicate passages of each single-cell clone used in this study. Each data point indicates mean \pm s.D. $(n=3)$. 
phenomenon remains to be investigated. However, it is possible that the characteristic of cell type-specific production of pituitary hormones by different pituitary cell types in the rainbow trout pituitary gland is maintained only when cells are arranged in the specific location in the intact pituitary gland. Once the pituitary cells are dissociated and maintained in culture, due to changes in the extracellular environment, pituitary cells may lose their cell type specificity with respect to the production of pituitary hormones. This hypothesis may be supported by the finding in this study that none of the five single-cell lines expresses pit-1 mRNA.

Another important characteristic for a useful pituitary cell line is its response to factors that are known to regulate the expression of pituitary hormone genes. Studies reported by Elango et al. (2006) showed that the production of Gh and $\mathrm{Prl}$ in trout pituitary explant cultures was induced by $\mathrm{E}_{2}$ and $o, p^{\prime}$-DDT. In the current study, we have shown that addition of $\mathrm{E}_{2}$, dexamethasone, or $o, p^{\prime}$-DDT resulted in a significant increase in the levels of $g h$ and $p r l$ mRNAs in mRTP1E cells. Furthermore, the capacity of the single-cell clone lines to respond to induction of $g h$ mRNA by $\mathrm{E}_{2}$ is independent of passage numbers. These results suggest that the mRTP single-cell clones that we developed in this study are fully functional. These single-cell clones can be used not only to determine factors that regulate the expression of pituitary hormone genes, but also as an in vitro rapid screening system for detecting environmental endocrine disruptors.

\section{Declaration of interest}

The authors declare that there is no conflict of interest that could be perceived as prejudicing the impartiality of the research reported.

\section{Funding}

This research was supported by a grant from US Department of Agriculture (CONTR 58-1930-0-009) to TTC.

\section{Acknowledgements}

The authors thank Mr Jon Larson for critically reading the manuscript.

\section{References}

Bols NC \& Lee LE 1991 Technology and uses of cell cultures from the tissues and organs of bony fish. Cytotechnology 6 163-187.

Bols NC \& Lee LE 1994 Cell lines: availability, propagation and isolation. In Biochemistry and Molecular Biology of Fishes, vol 3, pp 145-159. Eds PW Hochachka \& TP Mommsen. Amsterdam: Elsevier Science.

Bols NC, Yang B-Y, Lee LE \& Chen TT 1995 Development of a rainbow trout pituitary cell line that express growth hormone, prolactin, and somatolactin genes. Molecular Marine Biology and Biotechnology 4 154-163.
Chen MJ, Chiou PP, Yang B-Y, Lo HC, Son J-K, Hendrick J, Bailey G \& Chen TT 2004 Development of rainbow trout hepatoma cell lines: effect of pro-IGF-I Ea4-peptide on morphological changes and anchorageindependent growth. In Vitro Cellular \& Developmental Biology. Animal 40 $118-128$.

Chomczynski K \& Sacchi N 1987 Single-step method of RNA isolation by acid guanidinium thiocyanate-chloroform extraction. Analytical Biochemistry 162 156-159.

Chomczynski P, Brar A \& Frohman LA 1988 Growth hormone synthesis and secretion by a somatomammotroph cell line derived from normal adult pituitary of the rat. Endocrinology 123 2272-2283.

Doerr-Schott J 1976 Immunohistochemical detection, by light and electron microscopy, of pituitary hormones in cold-blooded vertebrates. 1, Fish and amphibians. General and Comparative Endocrinology 28 487-512.

Elango A, Shepherd B \& Chen TT 2006 Effects of endocrine disrupters on expression of growth hormone and prolactin mRNA in the rainbow trout pituitary. General and Comparative Endocrinology 145 116-127.

Farbridge KJ \& Leatherland JP 1986 A comparative immunohistochemical study of the pars distalis in six species of teleost fishes. Fish Physiology and Biochemistry 1 63-74.

Follenius E, Doerr-Schott J \& Dobuis MP 1978 Immunocytology of primary cells from teleost fishes. International Review of Cytology 54 193-223.

Fujiwara T, Oda K, Yokota S, Takatsuki A \& Ikehara Y 1988 Brefeldin A causes dissembly of golgi complex and accumulation of secretory proteins in the endoplasmic reticulum. Journal of Biological Chemistry 263 18545-18552.

Gonzalez-Villasenor LI \& Chen TT 1999 Antibodies for growth hormone and prolactin using multiple antigen peptide immunogens. Marine Biotechnology 1 211-220.

Gustasaw KM, Zurcher V, Dickerman LH, Stallard R \& Wilard HF 1994 Partial X chromosome trisomy with functional disomy of Xp due to failure of X inactivation. American Journal of Medical Genetics 53 39-45.

Kuo Y-H \& Chen TT 2002 Novel activities of pro-IGF-I E-peptides: regulation of morphological differentiation and anchorage-independent growth in human neuroblastoma cells. Experimental Cell Research 280 75-89.

Le Goff P, Wei C, Valotaire Y, Gonnard JE \& Prunet P 1992 Effect of somatostatin on prolactin in rainbow trout (Oncorhyynchus mykiss) pituitary cells in primary culture. Journal of Molecular Endocrinology 9 137-146.

Nagahama Y, Olivereau M, Farmer SW, Nagahama RS \& Bern HA 1981 Immunocytochemical identification of the prolactin- and growth hormone-secreting cells in the teleost pituitary with antisera to tilapia prolactin and growth hormone. General and Comparative Endocrinology 44 389-395.

Ono M, Takayama Y, Rand-Weaver M, Sakata S, Yasunaga T \& Kawauchi H 1990 cDNA cloning of somatolactin, a pituitary protein related to growth hormone and prolactin. PNAS 87 4330-4333.

Ool GT, Tawadros N \& Escalona RM 2004 Pituitary cell lines and their endocrine application. Molecular and Cellular Endocrinology 228 1-21.

Philips RB 2001 Application of fluorescence in situ hybridization (FISH) to fish genetics and genome mapping. Marine Biotechnology 3 S145-S152.

Rand-Weaver M, Noso T, Muramoto K \& Kawauchi H 1991 Isolation and characterization of somatolactin, a new protein related to growth hormone and prolactin from Atlantic cod (Gadus morhua) pituitary glands. Biochemistry 30 1509-1515.

Ribeiro L \& Ahne W 1982 Fish cell culture: intiation of a line of pituitary cells from carp (Cryrinus carpio) to study the release of gonadotropin in vitro. In Vitro 18 419-420.

Saga T, Yamaki K-I, Doi Y \& Yoshizuka M 1999 Chronological study of the appearance of adenohypophysial cells in the ayu (Plecoglossus altivelis). Anatomy and Embryology 200 469-475.

Shamblott MJ \& Chen TT 1992 Identification of a second insulin-like growth factor in a fish species. PNAS 89 8913-8917. 
Tashjian AH Jr, Yasymura Y, Levine L, Sato GH \& Parker ML 1968 Establishment of clonal strains of rat pituitary tumor cells that secrete growth hormone. Endocrinology 82 342-352.

Tashjian AH, Bancroft FC \& Levine L 1970 Production of both prolactin and growth hormone by clonal strains of rat pituitary tumor cells. Journal of Cell Biology 47 61-70.

Tian XC, Chen M, Pantschenko AG, Yang TJ \& Chen TT 1999 Recombinant E-peptides of pro-IGF-I have mitogenic activity. Endocrinology 140 3387-3390.

Yada T, Urano A \& Hirano T 1991 Growth hormone and prolactin gene expression and release in the pituitary of rainbow trout in serum-free culture. Endocrinology 129 1183-1192.
Yang TJ 1975 Inhibitory effects of phytohemagglutin on growth of leukemia lymphoblasts L5178Y in vitro and in vivo. Journal of the National Cancer Institute 55 323-327.

Yasumura Y, Tashjian AH \& Sato G 1966 Establishment of four functional clonal strains of animal cells in culture. Science 154 1186-1189.

Received in final form 29 December 2009

Accepted 19 January 2010

Made available online as an Accepted Preprint

19 January 2010 